\title{
Study of Cystatin C in Early Detection of Renal Impairment in Patient with HIV/AIDS
}

Ikpeama Osita John ${ }^{1 *}$, Okafor Patrick Adimabua ${ }^{2}$, Onuzulike Nonye Mariam ${ }^{1}$, Ikpeama Chizoba Anthonia $^{3}$, Ikpeama Chinwe Joy ${ }^{4}$, Igbineweka Osa Osazuwa ${ }^{5}$, Ikpeama Emeka Andrew ${ }^{6}$, Ofuenyi $\mathrm{Jacob}^{7}$, Nwosu Nchedochukwu Paulastella ${ }^{8}$, Ibeh Isaiah Nnanna ${ }^{9}$, Gerald Chukwudi Mokwe ${ }^{10}$, Ogwuegbu Juliet Uchechi ${ }^{11}$

${ }^{\mathrm{T}}$ Department of Public Health Imo State University, Owerri, Nigeria

${ }^{2}$ school of Medical Laboratory Sciences Ahmadu Bello University Teaching Hospital, Zaria, Kaduna State, Nigeria

${ }^{3}$ Federal Medical Centre Kebbi State, Nigeria

${ }^{4}$ Medicine San Frontires, Nigeria

${ }^{5}$ Department of Periodontology and Community Dentistry, University College Hospital, Ibadan

${ }^{6}$ Anatomy Department Anambra State University Uli, Nigeria

${ }^{7}$ Livon Medical Diagnostic Laboratory Service No 1 Cold Room Street, Beside Maddala Hotel, Niger State, Nigeria

${ }^{8}$ New Salvation Medical Centre, Sapele Delta State, Nigeria

${ }^{9}$ Department of Medical Laboratory Sciences, University of Benin, Nigeria

${ }^{10}$ Altinez Pharmaceutical Ltd 8 Obukun Street, Off Coker Road, Ilupeju, Lagos, Nigeria

${ }^{11}$ Department of Medicine, Imo State University, Owerri, Nigeria

\section{*Corresponding Author}

Ikpeama Osita John

\section{Article History}

Received: 13.06 .2020

Accepted: 03.07.2020

Published: 09.07.2020

\begin{abstract}
Human immunodeficiency virus (HIV) related kidney disease is one of the leading causes of death worldwide most especially in Nigeria. To access the possibility of detecting a more sensitive biomarker for early detection of renal disease in HIV/AIDS patients. Patients who are willing were randomly sellected using inclusion and exclusion criteria. Serum creatinine, Cystatin $\mathrm{C}$ and Urea were evaluated in two hundred newly diagnosed HIV seropositive patients, two hundred HIV/AIDS patients on therapy $(\mathrm{CD} 4<250)$, two hundred HIV/AIDS on therapy (CD4>250) and one hundred and fifty apparently healthy HIV seronegative individuals as control using standard method. Data analysis was done using Statistical Package for Social Science (SPSS) software package.Correlation study was by Pearsons Correlation Coefficient. Results were expressed as mean + SEM. Student t-test was used to compare differences between means. Results shows a significant increase in the levels of creatinine, cystatin $\mathrm{c}$ and urea levels in newly diagnosed HIV/AIDS patients when compared with control groups $p<0.05$. There was no significant diference in other parameters in both groups $p>0.05$. There was a significant diference between the values of creatinine, cystatin $c$ and urea recorded in HIV/AIDS patients with CD4 count of $<250$ cells $/ \mu 1$ when compared with control group $\mathrm{p}<0.05$. There were no significant difference in other parameters recorded in both groups $p>0.05$. There was a significant diference between the values of creatinine,cystatin $\mathrm{c}$ and urea recorded in HIV/AIDS patients with CD4 count of $>250$ cells/ $\mu$ l when compared with control group $\mathrm{p}<0.05$. There were no significant difference in other parameters recorded both groups $\mathrm{p}>0.05$. It could be concluded from this study that cystatin c could be used as a sensitive renal marker for early detection of renal disease in HIV/AIDS patients.
\end{abstract}

Keywords: Cystatin C, renal marker, HIV/AID, urea, creatinine.

Copyright @ 2020: This is an open-access article distributed under the terms of the Creative Commons Attribution license which permits unrestricted use, distribution, and reproduction in any medium for non commercial use (NonCommercial, or CC-BY-NC) provided the original author and source are credited. 


\section{INTRODUCTION}

The first report of AIDS-related renal failure, which we now recognize as HIV-associated nephropathy (HIVAN), was published in the mid-1980s [1]. Before effective anti-retroviral therapy became available, HIVAN was so frequent, and its clinical features were so dramatic; beginning with heavy proteinuria, with rapid progression to end-stage renal disease (ESRD). In immune-suppressed patients, HIVAN became almost synonymous with HIV-associated chronic kidney disease (CKD). As HIV infection spread, the ESRD incidence increased substantially, and by the early 1990s, HIVAN became the third leading cause of ESRD in HIV patients aged 20-64 years [2]. Kidney disease tends to be asymptomatic and is usually not the primary focus of a visit to an HIV clinic [3]. The presence of kidney disease should be anticipated; screening and proper interpretation of the relationship between serum creatinine level and GFR are recommended. Just as optimal control of HIV replication is achievable for most patients, so also is control of hypertension and diabetes. The future holds enormous opportunities for research in new markets for early detection of kidney disease, prevention strategies, novel therapeutics, and a better understanding of the interaction between black race and kidney disease. Until that time, the incidence and spectrum of kidney diseases in HIV-infected patients have been altered by the widespread use of highly active antiretroviral therapy (HAART). The clinical cause of kidney disease is more indolent, the risk of ESRD has been reduced by $40 \%-60 \%$, the 1-year survival rate while undergoing dialysis has increased from $25 \%$ to $75 \%$, and kidney transplantation is a viable option [4]. Despite these improvements, risk factors for kidney disease are highly prevalent among HIV-infected patients, and kidney disease remains a significant cause of morbidity and mortality, even among those patients receiving Highly Active Anti-Retroviral Therapy (HAART) Gupta et al. [3]. The kidneys are known reservoirs for persistent HIV replication, even when the peripheral viral load is suppressed with HAART [5]. The kidneys of patients with HIV-associated nephropathy have a dense tubulointerstitial inflammatory infiltrate that is primarily composed of activated $\mathrm{CD}_{4}{ }^{+}$and $\mathrm{CD}_{8}{ }^{+}$cells, and the amount of the infiltrate appears to correlate with the degree of clinical nephropathy [6]. It has been suggested that HIV-infected renal tubular epithelial cells trigger up-regulation of proinflammatory genes [7]. This proinflammatory renal environment may stimulate increased immune activation in the kidneys, which consequently may lead to heightened systemic immune activation. Alternatively, patients with increased systemic immune activation may be prone to infiltration of activated $\mathrm{T}$ cells into the kidneys, thereby leading to proteinuria and reduced renal function. Chronic renal disease (CKD) is defined as kidney damage or reduced kidney function that persists for $>3$ months [8]. A useful indicator of kidney damage is elevated urinary protein excretion, measured qualitatively with use of a urine dipstick or measured quantitatively with use of a spot urine protein to creatinine ratio (or 24-h urine collection). Kidney function can be reliably estimated from the serum creatinine by calculating the creatinine clearance or glomerular filtration rate (GFR) through use of the Cockcroft-Gault equation or modification of diet in renal disease (MDRD) equations, respectively. A GFR $<60 \mathrm{~mL} / \mathrm{min}$ meets criteria for CKD, a cutoff supported by epidemiologic data linking lower GFR to an increased frequency of hospitalization, cardiovascular events, or death. MDRD equations have been specifically validated in the HIV-infected population. The MDRD equation was derived from patients with low GFR and therefore can yield variable results in persons with normal renal function [9]. Nonetheless, these estimates remain the most highly validated formulas available, and both equations are more sensitive than measurement of serum creatinine alone. Cystatin $\mathrm{C}$ is freely filtered at the glomerulus. After filtration, Cystatin $\mathrm{C}$ is reabsorbed and catabolized by the tubular epithelial cells, with only small amounts excreted in the urine. Cystatin $\mathrm{C}$ levels are therefore measured not in the urine, but in the bloodstream. Equations have been developed linking estimated GFR to serum cystatin $C$ levels. Most recently, some proposed equations have combined (sex, age and race) adjusted cystatin $\mathrm{C}$ and creatinine. The most accurate is (sex, age and race) adjusted cystatin $\mathrm{C}$, followed by (sex, age and race) adjusted creatinine and then cystatin $C$ alone in slightly different with adjusted creatinine [10]. Problems with creatinine (varying muscle mass, recent meat ingestion (much less dependent on the diet than urea), have led to evaluation of alternative agents for estimation of GFR. One of these is cystatin C, a ubiquitous protein secreted by most cells in the body (it is an inhibitor of cysteine protease). However, blood urea nitrogen (BUN) and creatinine will not be raised above the normal range until $60 \%$ of total kidney function is lost. Hence, the more accurate Glomerular filtration rate or its approximation of the creatinine clearance is measured whenever renal disease is suspected or careful dosing of nephrotoxic drugs is required.

\section{Statement of Problem}

HIV/AIDS patients are on the increase all over the globe most importantly in Nigeria. The use of HAART in our entire medical centers for the management of this group of patients has tremendously improved the well beings of this group of patients. Early detection of renal complication associated with HIV/AIDS could help reduce their morbidity and mortality rate; hence there is need for the identification of a more sensitive biomarker for early detection of renal disease.

\section{Justification}

(a)The level of serum creatinine, urea and cystatin c in HIV/AIDS is not known in Ihugh, vandekya Local government area of Benue state, Nigeria. 
(b) There is need for the use of a more sensitive biochemical marker for accessing renal function in patients with HIV/AIDS.

(c) The prevalence of HIV/AIDS related renal disease is not known in Ihugh, vandekya Local government area of Benue state, Nigeria.

\section{Aim ANd OBJECTIVES}

To detect a more sensitive biomarker for early detection of renal disease in HIV/AIDS patients. The parameter to be assayed are serum cystatin c, urea, creatinine.

\section{Specific Objectives of the Study}

i. To evaluate the serum creatinine, urea and cystatin c level in newly diagnosed HIV patients and the control group.

ii. To evaluate the serum creatinine, urea and cystatin c level in HIV patients with CD4 $\leq 250$ cell/ $\mu$ l and the control group.

iii. To evaluate the serum creatinine, urea and cystatin c level in HIV patients with CD4 $\geq 250$ cell/ $\mu$ l and the control group.

\section{Description of study area}

Seven hundred and fifty patients attending medical treatment in St Thomas hospital Ihugh. Ihugh is situated in Vandeikya Local government area of Benue State which is located between latitude $70^{\circ} \mathrm{N}$ by Gboko and Buruku Local Governments Areas, in the South by Vandeikya Local Government, in the East by Kwande and in the West by Konshisha Local Government Area, Nigeria.

\section{Total number of population size}

The sample size is Seven hundred and fifty patients, comprised of two hundred newly diagnosed HIV seropositive patients, two hundred HIV/AIDS on therapy $\left(\mathrm{CD}_{4} \geq 250\right)$, two hundred HIV/AIDS on therapy $\left(C D_{4} \leq 250\right)$ and one hundred and fifty apparently healthy HIV seronegative individuals as control.

\section{Ethical Consideration}

Approval for the study was obtained from St Thomas hospital Ihugh medical advisory committee. Informed consent of the patients was also obtained. Patient's anonymity was maintained; the data generated was treated with strict confidentiality, and was used for the purpose of this research only.

\section{Sample size}

Using the formula

Where,

n

$$
=\frac{\mathrm{pq}}{[\mathrm{E} / 1.96]^{2}}
$$

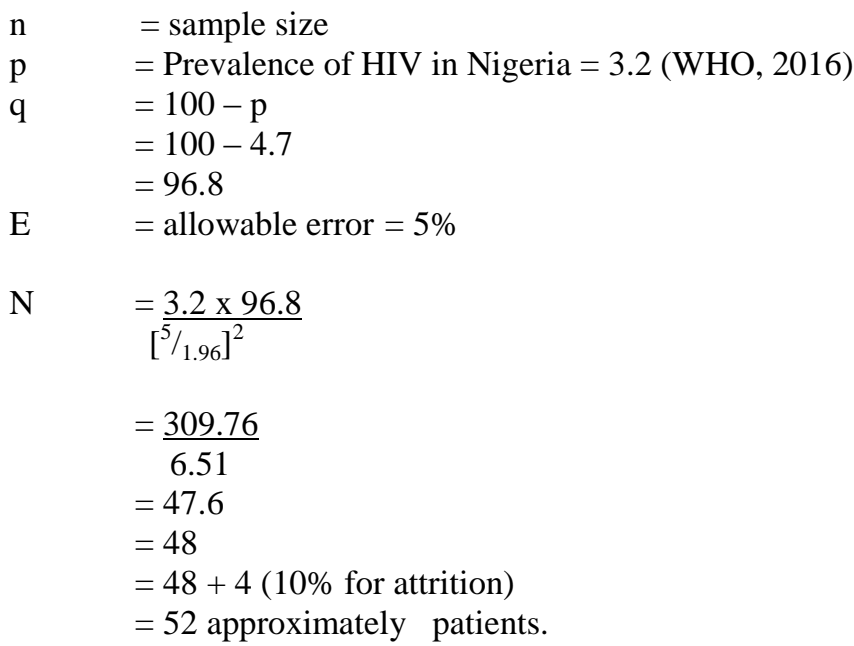




\section{Inclusion Criteria}

(i)All adult HIV seropositive patients who consent to be enrolled into the study

(ii)All adult HIV seropositive patients without any sign and symptom of renal disease

(iii)All adult HIV seropositive, patients without of any underlying disease like diabetes, hypertension

\section{Exclusion Criteria}

(i)All adult HIV seropositive patients who did not consent to be enrolled into the study

(ii)All adult HIV seropositive patients with sign and symptom of renal disease

(iii)All adult HIV seropositive patients with underlying disease like diabetes, hypertension

\section{Collection of Samples}

Ten $\mathrm{ml}$ of blood samples were collected in plain bottle. This was allowed to clot within 30 minutes of collection. The samples were then centrifuged at $3000 \mathrm{rpm}$ for 5 minutes to obtain neat serum samples, which were harvested into bijou bottles and labeled accordingly. The serum samples were stored at $4^{\circ} \mathrm{c}$ until assayed. EDTA tube was used to collect the sample for CD4 assay and assayed immediately.

\section{Anal ytical Methods}

\section{Cd4 easy count cyflow assay}

Principle: CD4-PE florescence can be analysed on a Partec flow Cytometer with an excitation light source of $532 \mathrm{~nm}$ (blue or green solid state laser). The Cyflow counter is set to counting CD4+T -cell per $\mu 1$ whole cell as displayed automatically by the instrument software which is controlled by an operator [11].

\section{Procedure}

i. $20 \mu 1$ whole blood (EDTA as anticoagulant) was added into a Partec tube.

ii. $20 \mu \mathrm{l}$ of CD4 mAb PE reagent was added to (i) above. Mixed gently and incubated for 15 minutes at room temperature protected from light.

iii. $800 \mu 1$ of no-lyse buffer was added to (ii) and vortexed gently.

iv. Test sample in (iii) was fed into Partec cyflow device and reading taken.

\section{Serum creatinine Assay}

Serum creatinine was estimated using the method $[12,13]$.

\section{Principle}

In an alkaline medium picrate react with creatinine to form a yellow color complex which is read colorimetrically at $490 \mathrm{~nm}$

\section{Reagent}

Ra Picric acid 35mmol/1, Rb Sodium hydroxide 1.6mmol/l

\section{Standard Concentraton}

\section{Analytical procedure}

i. $0.5 \mathrm{ml}$ of reagent $\mathrm{Ra}$ and $\mathrm{Rb}$ each was added into a tube labeled sample, standard and blank and mixed well

ii. $0.1 \mathrm{ml}$ of distilled water added to blank tube to zero the colorimeter

iii. $0.1 \mathrm{ml}$ of sample added to sample tube mixed and absorbance read at time (A1) and at (A2) immediately and after

$30 \mathrm{sec}$, same for standard.

Change of absorbance for both sample and standard was calculated as below.

Calculation: $\mathrm{A} 2-\mathrm{A} 1=\Delta \mathrm{A}$

$\Delta \mathrm{A}$ test $\times$ concentration of the standard $(2.07 \mathrm{mg} / \mathrm{dl})$

$\Delta$ Astd

\section{Diacethylmonoxine Method for Urea}

Principle: Urea react with hot acidic diacetylmonoxime in presence of thiosemicarbazide and produce a rose purple complex, which is measured colorimetrically $[13,14]$.

Reagent (Randox laboratory Ltd, Supplied in the kit)

Reagent 1: Urea reagent

Reagent 2: Diacetylmonoxime (DAM) 
Reagent 3: Working urea standard, $80.77 \mathrm{mg} / \mathrm{dl}$

Procedure:

i. $2.5 \mathrm{ml}$ of reagent $\mathrm{R} 1$ was added in the blank, test, and standard labeled tubes.

ii. $0.01 \mathrm{ml}$ of sample, urea standard(R3) was added in (i) labeled test and standard tubes respectively.0.01 ml of distilled water to blank tube.

iii. $0.25 \mathrm{ml}$ of DAM reagent(R2) was added to individual tubes. The tubes were Mixed well and kept in boiling water for

10 mintes and cool under running water for 5 minutes.

iv. The Optic density was measured colorimetrically at 520nm.

Calculation

$\underline{\text { OD of test }} \times 80.77 \mathrm{mg} / \mathrm{dl}$

OD of standard

\section{CYSTATIN C ASSAY \\ Assay Principle}

Diazyme's Cystatin C Assay is based on a latex enhanced immuno-turbidimetric assay. Cystatin C in the sample binds to the specific anti-Cystatin $\mathrm{C}$ antibody, which is coated on latex particles, and causes agglutination. The degree of the turbidity caused by agglutination can be measured optically and is proportional to the amount of Cystatin $\mathrm{C}$ in the sample. The value of serum Cystatin $\mathrm{C}$ concentration of the patient specimen was obtained by interpolation on the obtained signal of a 6-point calibration (standard) linear graph [15].

Reagent Composition

$\underline{\text { Reagent } 1}$

$100 \mathrm{mM}$ Tris-buffer solution, ready to use

\section{Reagent 2}

Suspension of anti-human Cystatin C chicken polyclonal antibody coated latex particles $(<0.5 \%)$, ready to use Ready to use liquid calibrators containing Cystatin C

\section{Procedure}

i. $250 \mu \mathrm{L}$ of reagent 1 was added to a labeled test sample tube containing $3 \mu 1$ sample incubated for $5 \mathrm{~min}$ at $37^{\circ} \mathrm{C}$.

ii. $250 \mu \mathrm{L}$ of reagent 1 was added to a labeled test standard tube containing $3 \mu 1$ standard incubated for $5 \mathrm{~min}$ at $37^{\circ} \mathrm{C}$.

iii. $50 \mu \mathrm{L}$ of reagent 2 was added to tube (i) and (ii).

iv. The absorbance read at $540 \mathrm{~nm}$ in $6 \mathrm{~min}$ and $10 \mathrm{~min}$ [10]. Change in absorbance was measured.

\section{Statistical Analysis}

Data collected were entered into IBM compatible microcomputer. Data analysis was done using Statistical Package for Social Science (SPSS) software package window 10 version 16. Correlation was by Pearsons Correlation Coefficient. The Mean and Standard Error of Mean (SEM) were computed and results were expressed as mean \pm SEM. Student t-test was used to compare differences between means.

\section{Result}

The results obtained in the present study are expressed as mean \pm standard error of mean (mean \pm SEM) and are presented in tables 4.1 to 4.3 and figure 4.1-4.2.

Table 4.1 shows the mean values of urea, creatinine, Cystatin C in newly diagnosed HIV patients and control groups. There were statistical significant increases in the mean values of Creatinine and Cystacin $\mathrm{C}$ recorded in newly diagnosed HIV patients compared with controls ( $\mathrm{p} \geq 0.05$ ). It also shows the mean \pm SEM value of Ages (yrs), Height (m), weight $(\mathrm{kg})$ and BMI in newly diagnosed HIV patients and controls. There were significant increases in the mean values of age, weight, BMI recorded in newly diagnosed HIV Patients compared with control groups $(p<0.05)$. There were Significant differences in the mean values of height, recorded in newly diagnosed HIV patients Compared with controls $(\mathrm{p}>0.05)$.

Table 4.2 shows the mean values of urea, creatinine, Cystatin C in HIV patients with CD $4 \leq 250$ and controls. There were no statistical significant increases in the mean values of creatinine, recorded in HIV patients with CD4 $\leq 250$ compared with controls $(\mathrm{p}<0.05)$. There was statistical significant increase in Cystatin $\mathrm{C}$, urea recorded in HIV patients with $C D 4 \leq 250$ compared with controls ( $\mathrm{p} \geq 0.05)$. It also shows the mean \pm SEM values of Age (yrs), Height (m), weight $(\mathrm{kg})$, BMI of HIV patients (CD4 $\leq 250)$ and Controls. There were significant increases in the mean values of age, weight 
and BMI recorded in HIV patients $(\mathrm{CD} 4 \leq 250)$ compared with controls $(\mathrm{p}<0.05)$ and there was no significant increase in the mean value of height of HIV patients $(\mathrm{CD} 4 \leq 250)$ recorded compared with control group.

Table 4.3 shows the mean values of urea, creatinine, Cystatin C in HIV Patients with CD4 $\geq 250$ and controls. There were no statistical significant increases in the mean values of creatinine and Cystatin C recorded in HIV Patients with CD4 $\geq 250$ cells $/ \mathrm{ml}$ compared with control groups $(\mathrm{p} \leq 0.05)$. There were Statistical significant difference in the mean value of urea recorded in HIV patients with CD4 $\geq 250$ compared with controls ( $p \geq 0.05)$. It also shows the mean \pm SEM of Ages (yrs), Height (m), weight (kg), BMI and P- Value HIV patients (CD4 $\geq 250$ ) and Controls. There were significant increases in the mean values of age, weight and BMI recorded in HIV patients (CD4 $\geq 250)$ compared with controls $(\mathrm{p}<0.05)$.

Figure 4.1. Shows strong correlation between plasma cystatin $\mathrm{C}$ to Serum Creatinine.Linear regression: cysC = $2.0464 \mathrm{CR}+0.666 ; \mathrm{r}=0.076 ;$ Regression $=0.9257 ; \mathrm{n}=150$.

Figure 4.2. Shows strong corellation between plasma cystatin $\mathrm{C}$ to Serum Urea.Linear regression: urea= 2.0813Cys C+23.035; $\mathrm{r}=0.0293$; Regression $=0.359 ; \mathrm{n}=150$.

Table-1: Shows the mean \pm SEM of creatinine, cystatin c, urea, Age (yrs), Height (m), weight (kg), BMI in newly diagnosed HIV patient comparing with control

\begin{tabular}{|c|c|c|c|c|c|c|c|}
\hline & $\begin{array}{c}\text { reatinine } \mathrm{mg} / \mathrm{dl} \\
\mathrm{X} \pm \mathrm{SEM}\end{array}$ & $\begin{array}{l}\text { cystatin c md/l } \\
\text { X } \pm \text { SEM }\end{array}$ & $\begin{array}{l}\text { urea mg/dl } \\
X \pm S E M\end{array}$ & $\begin{array}{l}\text { Ages (yrs) } \\
\text { X } \pm \text { SEM }\end{array}$ & $\begin{array}{l}\text { Height(m) } \\
\text { X } \pm \text { SEM }\end{array}$ & $\begin{array}{l}\text { weight }(\mathrm{kg}) \\
\mathrm{X} \pm \text { SEM }\end{array}$ & $\begin{array}{c}\text { BMI } \\
\mathrm{X} \pm \text { SEM }\end{array}$ \\
\hline Newly diagn & nosed $1.38 \pm 0.15$ & $2.17 \pm 0.31$ & $27.73 \pm 1.09$ & $39 \pm 0.7$ & $1.5 \pm 0.4$ & $58 \pm 0.8$ & $25.7 \pm 0.5$ \\
\hline Control & $0.73 \pm 0.02$ & $0.77 \pm 0.4$ & $27.36 \pm 0.33$ & $39 \pm 0.7$ & $1.5 \pm 0.4$ & $58 \pm 0.8$ & $25.7 \pm 0.5$ \\
\hline T-test value & 1.18 & 1.05 & 0.38 & 0.00 & 0.01 & 0.92 & 0.00 \\
\hline $\mathrm{P}$-value & $\mathrm{p} \leq 0.05$ & $\mathrm{p} \leq 0.05$ & $\mathrm{p} \leq 0.05$ & $\mathrm{p} \geq 0.05$ & $\mathrm{p} \geq 0.05$ & $\mathrm{p} \geq 0.05$ & $\mathrm{p} \geq 0.05$ \\
\hline
\end{tabular}

They were statistical significant difference in creatinine, cystatin c, urea, age, height, weight and BMI in newly diagnosed HIV patients high than in control subject. There was slight significant increase in cystatin $\mathrm{c}$ and creatinine in newly diagnosed HIV patients high than in control subject. There was no increase in the age, height, weight and BMI across the subjects.

Table-2: Shows the mean \pm SEM of creatinine, cystatin c, urea, Age (yrs), Height (m), weight (kg), BMIin HIV patient with $\mathrm{CD} 4 \leq \mathbf{2 5 0}$ cell $/ \mu \mathrm{l}$ comparing with control

\begin{tabular}{|c|c|c|c|c|c|c|c|}
\hline & $\begin{array}{c}\text { Creatinine mg/dl } \\
\text { X } \pm \text { SEM }\end{array}$ & $\begin{array}{l}\text { cystatin c mg/l } \\
X \pm S E M\end{array}$ & $\begin{array}{c}\text { urea mg/dl } \\
X \pm \text { SEM }\end{array}$ & $\begin{array}{l}\text { Ages (yrs) } \\
X \pm \text { SEM }\end{array}$ & $\begin{array}{l}\text { Height(m) } \\
X \pm \text { SEM }\end{array}$ & $\begin{array}{l}\text { weight(kg) } \\
\text { X } \pm \text { SEM }\end{array}$ & $\begin{array}{l}\text { BMI } \\
\text { X } \pm \text { SEM }\end{array}$ \\
\hline $\mathrm{CD} 4 \leq 250 \mathrm{c}$ & cell $/ \mu 10.94 \pm 0.03$ & $1.23 \pm 0.09$ & $26.46 \pm 0.33$ & $27 \pm 0.6$ & $1.5 \pm 0.1$ & $57 \pm 0.9$ & $25.3 \pm 0.2$ \\
\hline Control & $0.73 \pm 0.02$ & $0.77 \pm 0.4$ & $27.36 \pm 0.33$ & $25 \pm 0.7$ & $1.6 \pm 0.1$ & $55 \pm 0.1$ & $21.5 \pm 0.8$ \\
\hline T-test value & 5.19 & 1.17 & 0.10 & 0.00 & 0.00 & 0.00 & 0.00 \\
\hline $\mathrm{P}$-value & $\mathrm{p} \leq 0.05$ & $\mathrm{p} \leq 0.05$ & $\mathrm{p} \leq 0.05$ & $\mathrm{p} \geq 0.05$ & $\mathrm{p} \geq 0.05$ & $\mathrm{p} \geq 0.05$ & $\mathrm{p} \geq 0.05$ \\
\hline
\end{tabular}

They were statistical significant difference in cystatin c, urea, ages, height, weight and BMIin HIV patient with CD4 $\leq 250$ cell $/ \mu 1$ comparing with control. There were no statistical significant different of creatinine in HIV patient with CD4 $\leq 250$ cell $/ \mu$ l comparing with control. There were slight significant increase in urea and none in cystatin c, creatinine in HIV patient with CD4 $\leq 250$ cell/ $\mu$ l comparing with control subjects. There was significant increase in the ages, height, weight and BMI in in HIV patient with $\mathrm{CD} 4 \leq 250$ cell/ $\mu$ l comparing with control.

Table-3: Shows the mean \pm SEM of creatinine, cystatin c, urea Age (yrs), Height (m), weight (kg), BMI in HIV patient with $C D 4 \geq 250$ cell $/ \mu$ l comparing with control

\begin{tabular}{|c|c|c|c|c|c|c|c|}
\hline & $\begin{array}{c}\text { Creatinine mg/dl } \\
\text { X } \pm \text { SEM }\end{array}$ & $\begin{array}{l}\text { cystatin c mg/l } \\
\text { X } \pm \text { SEM }\end{array}$ & $\begin{array}{l}\text { urea mg/dl } \\
X \pm \text { SEM }\end{array}$ & $\begin{array}{c}\text { Ages (yrs) } \\
\text { X } \pm \text { SEM }\end{array}$ & $\begin{array}{l}\text { Height(m) } \\
\text { X } \pm \text { SEM }\end{array}$ & $\begin{array}{l}\text { weight(kg) } \\
\text { X } \pm \text { SEM }\end{array}$ & $\begin{array}{c}\text { BMI } \\
\text { X } \pm \text { SEM }\end{array}$ \\
\hline $\mathrm{CD} 4 \geq 250 \mathrm{c}$ & $\mathrm{ell} / \mu \mathrm{l} 0.89 \pm 0.02$ & $1.02 \pm 0.03$ & $27.37 \pm 0.39$ & $31 \pm 0.5$ & $1.6 \pm 0.2$ & $65 \pm 0.5$ & $25.3 \pm 0.7$ \\
\hline Control & $0.73 \pm 0.02$ & $0.77 \pm 0.4$ & $27.36 \pm 0.33$ & $25 \pm 0.7$ & $1.6 \pm 0.1$ & $55 \pm 0.1$ & $21.5 \pm 0.8$ \\
\hline T-test value & 2.30 & 3.34 & 0.49 & 0.00 & 0.21 & 0.00 & 0.00 \\
\hline $\mathrm{P}$-value & $\mathrm{p} \leq 0.05$ & $\mathrm{p} \leq 0.05$ & $\mathrm{p} \leq 0.05$ & $\mathrm{p} \geq 0.05$ & $\mathrm{p} \geq 0.05$ & $\mathrm{p} \geq 0.05$ & $\mathrm{p} \geq 0.05$ \\
\hline
\end{tabular}

They were statistical significant difference in urea HIV patient with CD4 $\geq 250$ cell/ $\mu 1$ comparing with control. There were no statistical significant different of creatinine and cystatin $\mathrm{c}$ in HIV patient with CD4 $\geq 250$ cell/ $\mu 1$ comparing with control. There were no significant increase in cystatin c, creatinine and urea in HIV patient with CD4 
$\geq 250$ cell $/ \mu$ l comparing with control subjects. There was significant increase in the ages, height, weight and BMI in in HIV patient with CD4 $\leq 250$ cell/ $\mu$ l comparing with control.

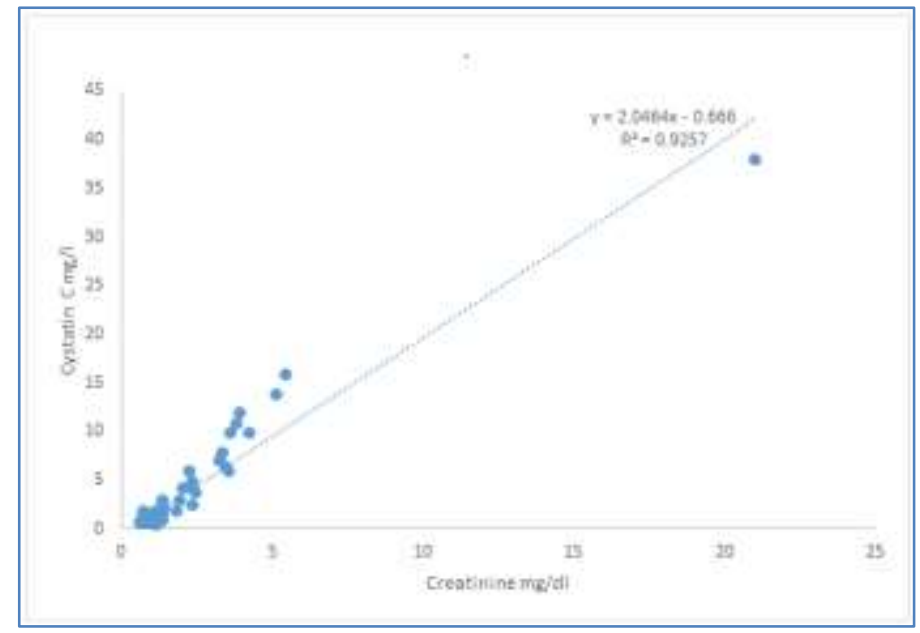

Fig-4.1: Relation of plasma Cystatin $C$ to Serum Creatinine. Linear correlation and regression: cys $C=2.0464 C R+0.666 ; r=0.076$; Regression=0.9257; $\mathbf{n = 1 5 0}$
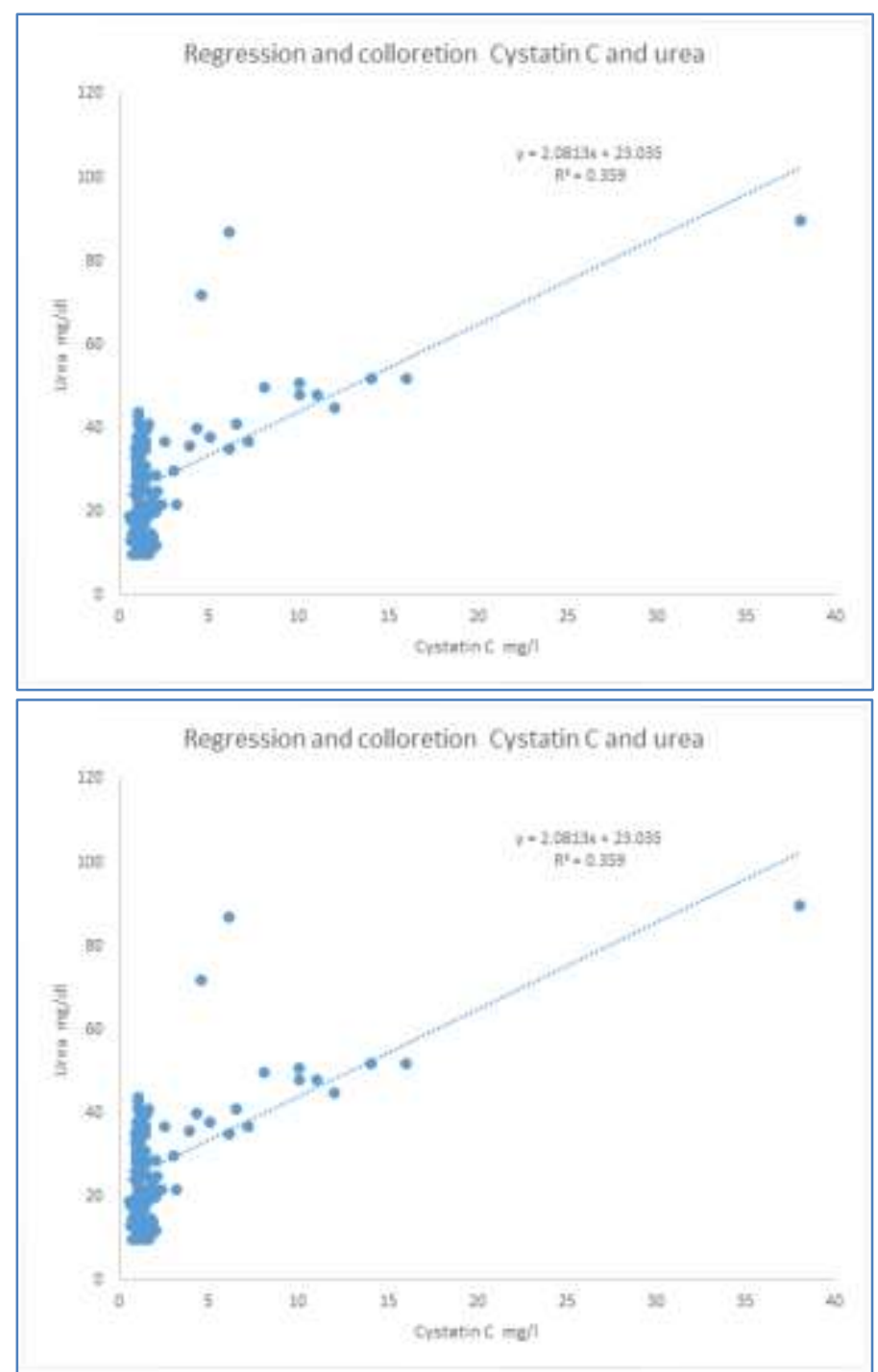

Fig-4.2: Relation of plasma Cystatin $C$ to Serum Urea. Linear regression: urea=2.0813Cys $C+23.035 ; r=0.0293$; Regression=0.359; $n=150$ 


\section{DiscuSsion, CONCLUSION AND RECOMMENDATION DISCUSSION}

HIV associated nephropathy, the most common renal disease in HIV patients was first described in 1984 [1, 16]. Most patients present with nephrotic syndrome, progressive loss of renal function and without treatment progress to end stage renal dysfunction (ESRD) within weeks to months [17]. Although HIV associated nephropathy is usually diagnosed late in the course of HIV infection, renal involvement can occur earlier, even during the acute retroviral syndrome prior to HIV antibody seroconversion.

There were significant increases in the mean values of urea, Creatinine, Cystatin $\mathrm{C}$ recorded in HIV patients compared with values in controls $(\mathrm{p}<0.05)$ table 4.1. Kara et al. [3] in a study of renal disease in an antiretroviral-naive HIV-infected outpatient population in Western Kenya obtained of 373 patients (subject), renal insufficiency $(\mathrm{CrCl}<60$ $\mathrm{ml} / \mathrm{min}$ ) was identified in $43(11.5 \%)(18(4.8 \%)$ had a $\mathrm{CrCl}<50 \mathrm{ml} / \mathrm{min})$. Despite high correlation coefficients between the three renal function estimating equations used, when compared to creatinine clearance as calculated by CockcroftGault, lower rates of moderate to severe renal insufficiency were identified by the Modification of Diet in Renal Disease equations. In another report by Doutora et al., [18] Strategies for early detection of renal injury in HIV-infected patients: the new troponin obtained themean (standard deviation) and median (inter-quartile range) for total of 242 patients (subject), 17 patients had elevated levels of Cystatin $\mathrm{C}$ but with an estimated creatinine clearance within normal range, 11 were on antiretroviral therapy with tenofovir and/or atazanavir. Fourteen patients were smokers and 10 patients had hepatitis $\mathrm{C}$ virus co-infection, which are known causes of inflammation. In a matched control group of 27 patients (subject) had Cystatin $\mathrm{C}$ within normal range, the majority of patients (subject) also were on an antiretroviral regimen with tenofovir and/or atazanavir. However, none of them had hepatitis $\mathrm{C}$ virus co-infection. Moreover, a statistical association was found between high levels of Cystatin $\mathrm{C}$ and alanine transaminase. Differences between biomarkers' levels and patients on combinations with tenofovir, ritonavir boosted atazanavir or both were also studied. Although there was no statistically significant difference in creatinine and estimated creatinine clearance, with Cystatin C, patients that were on atazanavir or tenofovir, had a higher level of Cystatin C, compared with patients that never were on these drugs. For instance, in a US study looking at body fat and metabolic changes in HIV-positive patients (the FRAM - Fat Redistribution and Metabolic Change in HIV Infection - cohort), investigators conducted a cross sectional sub-study where they compared kidney function, as measured by Cystatin C and creatinine levels in 1008 HIV-positive subjects and 208 HIV-negative controls [19]. Cystatin C measurements were consistently higher in the HIV-positive participants (at levels that would be indicative of poor outcomes in the general population) but creatinine-based eGFR levels were similar in HIV-infected individuals and controls. In a subsequent analysis of the FRAM cohort, Levels of Cystatin C were elevated in HIV-positive patients compared to the HIV-negative controls (mean level, $0.92 \mathrm{mg} / \mathrm{l} \mathrm{vs} .0 .76 \mathrm{mg} / \mathrm{l}, \mathrm{p}<$ 0.001). But creatinine levels were similar in the two groups of patients $(0.87 \mathrm{mg} / \mathrm{dl} \mathrm{vs} .0 .85 \mathrm{mg} / \mathrm{dl})$. Odden et al., [19] opined Cystatin C level elevated in HIV-infected individuals; the Mean \pm SD Cystatin C level was $0.92 \pm 0.22 \mathrm{mg} / \mathrm{L}$ in those infected with HIV and $0.76 \pm 0.15 \mathrm{mg} / \mathrm{L}$ in controls $(P<.001)$. In contrast, both mean creatinine levels and estimated glomerular filtration rates appeared similar in HIV-infected individuals and controls $(0.87 \pm 0.21 \mathrm{vs} 0.85 \pm 0.19 \mathrm{mg} / \mathrm{dl}$ (to convert to micromoles per liter, multiply by 88.4$)(P=.35)$ and $110 \pm 26$ vs $106 \pm 23 \mathrm{~mL} / \mathrm{min} / 1.73 \mathrm{~m}^{2}(P=.06)$, respectively). Persons with HIV infection were more likely to have a cystatin $\mathrm{C}$ level greater than $1.0 \mathrm{mg} / \mathrm{L}(\mathrm{OR}, 9.8$; 95\% confidence interval, 4.4-22.0 $(P<.001)$, a threshold demonstrated to be associated with increased risk for death and cardiovascular and kidney disease.

Another study using data from participants from the strategies for management of antiretroviral therapy (SMART) study found that Cystatin C and other biomarkers of serious health problems were elevated in people living with HIV as compared to the general population (based on data from two large studies monitoring the development of renal and heart disease), even while people were taking antiretroviral therapy [20]. "In summary", the investigators said, "we found that markers of inflammation, coagulation, and renal function were elevated in HIV-infected study participants receiving or not receiving antiretroviral therapy, compared with patients in two large population-based studies."

All of this would tend to support the fact that HIV causes kidney disorders and this increase the risk of poor outcomes in people living with HIV. However, Post et al., [21] quite correctly point out that "although changes in virologic control could plausibly influence kidney function, it is also possible that changes in Cystatin $\mathrm{C}$ reflect the influence of viral replication on systemic inflammation”.

In the present study, Cystatin $\mathrm{C}$ showed higher increment above control than serum creatinine in early stages of kidney affection HIV/AIDS nephropathy (table 4.1,4.2 and 4.3). A mild degree of renal dysfunction may develop unnoticed as creatinine level may remain in the normal range despite a major decline in GFR, and the use of serum 
creatinine may inaccurately estimate GFR due to dietary intake, tubular secretion of creatinine [22]. These results confirm those noticed by Coll et al. [23]. They reported that serum cystatin C levels started to increase when GFR was 88 $\mathrm{ml} / \mathrm{min} / 1.73 \mathrm{~m}^{2}$, while serum creatinine level began to increase when GFR was $75 \mathrm{ml} / \mathrm{min} 1.73 \mathrm{~m}^{2}$. These data indicate that serum cystatin C may detect mild reduction in GFR than serum creatinine. On the other hand, Shemesh et al., [24] reported that serum creatinine is of little value in estimating GFR, while increased serum creatinine with decreased GFR has been reported in patients with several types of renal failure [25]. Newman and price [26] have suggested cystatin C as the best endogenous GFR marker.

There were significant increases in the mean values of urea, Creatinine, Cystatin $\mathrm{C}$ recorded in HIV patients with $(\mathrm{CD} 4 \leq 250)$ compared with values obtained in controls $(\mathrm{p}<0.05)$ table 4.2 . These findings correlate with the works of Moses et al. [27]. They reported that the mean serum cystatin c levels were significantly higher in the HIV-infected patients when compared with the value in controls $(P<0.05)$. Direct effects of HIV appear to play a major role in the development of HIV- associated nephropathy, and are characterized histologically by collapsing glomerulosclerosis, thrombotic microangiopathy and various forms of immune complex glomerulonephritis. Hepatitis B and C co-infection, often co-pathogens with HIV, may affect kidneys similarly [28]. Kamga et al., [29] and Emejulu et al. [30], reported that serum urea concentrations were significantly increased $(\mathrm{p}<0.05)$ in both male and female patients compared to the controls. Although no significant difference was obtained in the serum creatinine levels of the patients to the control, correlation analysis revealed a positive association between creatinine and urea levels in both male $(\mathrm{r}=0.63)$ and female $(\mathrm{r}=0.68) \mathrm{HIV}$ patients, which is in consonance to this study since were no statistical significant increases in the mean values of Creatinine, recorded in HIV patients compared with values obtained in controls $(\mathrm{p} \leq 0.05)$ table 4.2. There was no statistical significant difference in creatinine and cystatin c, among HIV infected subject with $\mathrm{CD} \leq 250$ cell/ $\mu \mathrm{l}$ when compared to control as shown in table 4.2. There were statistical significant differences in the mean (increase) value of age, weight and BMI recorded in HIV patients with $C D \leq 250$ compared with controls $(\mathrm{p} \geq 0.05)$.

There was a significant increase in the mean value of urea recorded in HIV patients with CD4 $\geq 250$ cells $/ \mathrm{ml}$ compared with control groups $(\mathrm{p}<0.05)$. There were no significant differences in the mean values of creatinine, $c$ recorded in HIV patients compared with values in controls ( $p>0.05)$. HIV patients with (CD4 $\geq 250)$ had increased urea, Cystatin C when compared with Controls in table 4.2. This finding correlate with the work of Jerzy et al. [31], they reported that HIV patients had a significant increase in serum cystatin C concentration compared with apparently healthy individuals. There were no significant differences in urea and creatinine in both groups. In another report by Kamga, et al., 2011, reported that kidney function trends in human immunodeficiency virus/acquired immune deficiency syndrome (HIV/AIDS) patients at the Nylon District Hospital, Douala, Cameroon, age range of the study population was 18 to 60 years, showed no significant difference in urea, creatinine, proteinuria in HIV positives and control groups. There was no significant difference between proteinuria and microalbuminuria between control and HIV patients with CD4 $\geq 250$ ( $\mathrm{p} \geq$ $0.05)$.

There were no statistical significant difference in creatinine and cystatin c, among HIV infected subject with $\mathrm{CD} \leq 250 \mathrm{cell} / \mu \mathrm{l}$ and $\mathrm{CD} 4 \geq 250$ when compared to control as shown in table 4.3. There was no correlation $(r=0.076)$ between cysC and SCR (figure 4.1) which those not supports the concept that cysC and SCR have similar properties as plasma markers of GFR [32]. Correlation of cysC measurements with measurement of GFR has been reported in a number of previous studies by Grubb and coworkers [26, 33]. Grubb et al. [34] first reported the correlation $(r=0.75-$ 0.77) of (1/cysC] concentrations with GFR measured by Cr-EDTA clearance, and also found a similar correlation $(r=$ $0.73-0.75)$ for $(1 / \mathrm{SCr})$ vs $\mathrm{Cr}$-EDTA clearance in renal patients ranging in age from 7 to 77 years. Stronger correlation to Cr-EDTA clearance $(r=0.87)$ together with a greater distinction from the plasma SCr correlation $(r=0.71)$ were reported in a more recent study using a particle enhanced turbidimetric assay for cysC measurement in patients 8-81 years of age [33]. Similar numbers for the correlation of [1/cysC] vs Cr-EDTA clearance $(r=0.81)$ were reported in the most recent studies [35], but the correlation using SCR was markedly lower $(r=0.50)$. According to Stickle et al. 1998 in a study of pediatric patients there was high correlation between [cysC] vs Creatinine clearance $(r=0.77$ for 4-12 years; and $r=0.87$ for $12-19$ years) is comparable with the correlations obtained in previous studies. There was no correlation of cystatin $\mathrm{C}$ with urea ( $\mathrm{r}=0.0293$ ) (figure 4.2).

\section{CONCLUSION}

Cystatin $\mathrm{C}$ levels may be increased in inflammatory conditions. Therefore, in HIV-infected patients, where chronic systemic inflammation is present, often associated to other inflammation sources, such as chronic hepatitis $\mathrm{C}$ virus co-infection, the use of Cystatin $C$ to monitor kidney function may overestimate kidney impairment. It is important to develop prospective studies, in order to assess and determine early renal dysfunction and real long-time impact of the 
more recent antiretroviral drugs on kidney function so as to take preventive measure on kidney diseases which is the core Public health population strategies.

\section{RECOMMENDATION}

An estimate of creatinine clearance for GFR is also recommended annually to screen for renal dysfunction that may develop overtime and that may herald worse overall prognosis. Renal disease is frequent in patients having HIV/AIDS infection. There is need for inclusion of a sensitive (Cystatin C) renal marker as a routine check in these patients. This will help in early detection of renal diseases, thereby preventing end stage renal disease.

\section{REFERENCES}

1. Rao, T. S., Filippone, E. J., Nicastri, A. D., Landesman, S. H., Frank, E., Chen, C. K., \& Friedman, E. A. (1984). Associated focal and segmental glomerulosclerosis in the acquired immunodeficiency syndrome. New England Journal of Medicine, 310(11), 669-673.

2. Klotman, R. H. (1996). Teaching strings: Learning to teach through playing. Schirmer Books.

3. Wools-Kaloustian, K., Gupta, S. K., Muloma, E., Owino-Ong’or, W., Sidle, J., Aubrey, R. W., ... \& Goldman, M. (2007). Renal disease in an antiretroviral-naive HIV-infected outpatient population in Western Kenya. Nephrology Dialysis Transplantation, 22(8), 2208-2212.

4. US Renal Data System. (2013). USRDS 2013 annual data report: atlas of chronic kidney disease and end-stage renal disease in the United States.

5. Winston, J. A., Bruggeman, L. A., Ross, M. D., Jacobson, J., Ross, L., D'Agati, V. D., ... \& Klotman, M. E. (2001). Nephropathy and establishment of a renal reservoir of HIV type 1 during primary infection. New England Journal of Medicine, 344(26), 1979-1984.

6. Kimmel, P. L. (2003). HIV-associated nephropathy: virologic issues related to renal sclerosis. Nephrology Dialysis Transplantation, 18(suppl_6), vi59-vi63.

7. Ross, M. J., Fan, C., Ross, M. D., Chu, T. H., Shi, Y., Kaufman, L., .. \& Klotman, P. E. (2006). HIV-1 infection initiates an inflammatory cascade in human renal tubular epithelial cells. JAIDS Journal of Acquired Immune Deficiency Syndromes, 42(1), 1-11.

8. Coresh, J., Astor, B. C., Greene, T., Eknoyan, G., \& Levey, A. S. (2003). Prevalence of chronic kidney disease and decreased kidney function in the adult US population: Third National Health and Nutrition Examination Survey. American journal of kidney diseases, 41(1), 1-12.

9. Stevens, L. A., Coresh, J., Feldman, H. I., Greene, T., Lash, J. P., Nelson, R. G., ... \& Levey, A. S. (2007). Evaluation of the modification of diet in renal disease study equation in a large diverse population. Journal of the American Society of Nephrology, 18(10), 2749-2757.

10. Stevens, L. A., Coresh, J., Schmid, C. H., Feldman, H. I., Froissart, M., Kusek, J., ... \& Greene, T. (2008). Estimating GFR using serum cystatin $\mathrm{C}$ alone and in combination with serum creatinine: a pooled analysis of 3,418 individuals with CKD. American journal of kidney diseases, 51(3), 395-406.

11. Fryland, M.(2006). The parteccyflow counter for CD4 T cell counting produce high quality results and robust field under routine field condition in Malawi. Transient Royal Society Tropical Medicine and Hygiene, 100: 980-985

12. Jaffe, M. (1886). Hoppe-Seylers Z. physiol. Chem, 10, 391.

13. Robert, T., Bartel, M., \& Offergeld, G. (1972). Characterization of oxygen species adsorbed on copper and nickel oxides by X-ray photoelectron spectroscopy. Surface Science, 33(1), 123-130.

14. Förste, C., Bruinsma, S., Abrikosov, O., Flechtner, F., Marty, J. C., Lemoine, J. M., \& Biancale, R. (2014, May). EIGEN-6C4-The latest combined global gravity field model including GOCE data up to degree and order 1949 of GFZ Potsdam and GRGS Toulouse. In EGU general assembly conference abstracts (Vol. 16).

15. Erlandsen, E.J, Randers, E., \& Kristensen, J.H. (1999). Evaluation of the Dade Behring N Latex Cystatin C assay on the Dade Behring Nephelometer II System. Scandinavian Journal of Clinical Laboratory Investigation, 59: 1-8.

16. Pardo, V., Aldana, M., \& Cotton, R.M. (1984). Glomerular lesions in the acquired immunodeficiency syndrome. Annal of Internal Medicine, 101: 429-34.

17. Langs, C., Gallo, G.R., \& Schacht, R.G. (1990). Rapid renal failure in AIDS-associated focal glomerulosclerosis. Archives of Internal Medicine, 150:287-292.

18. Doutora, E. V., Faculdade, M. L., Brilha, S. S. S. (2011). Strategies for early detection of renal injury in HIVinfected patients: the new troponin. Universidade de lisboa, faculdade de medicina

19. Odden, M.C., Scherzer, R., \& Bacchetti, P. (2007). "Cystatin C level as a marker of kidney function in human immunodeficiency virus infection: the FRAM study". Archives of Internal Medicine, 167(20): 2213-2219.

20. Neuhaus, J. (2010). Markers of inflammation, coagulation, and renal function are elevated in adults with HIV infection. Journal of Infectious Diseases, 201:455-475 
21. Post, F.A., Wyatt, C.M., \& Mocroft, A. (2010). Biomarkers of impaired renal function Current Opinion in HIV \& AIDS. AIDS5 (6): 524-530,

22. Kyhse-Andersen, J., Schmidt, C., \& Nordin, G. (1994). Serum cystatin C, determined by a rapid, automated particleenhanced turbidimetric methods is a better marker than serum creatinine for glomerular filtration rate. Clinical Chemistry, 90:192-6

23. Coll, I., Casanovas, A. M., Vial, L., Gleizes, A., \& Casanovas, J. (2000). Chemical kinetics modelling of a decaying SF6 arc plasma in the presence of a solid organic insulator, copper, oxygen and water. Journal of Physics D: Applied Physics, 33(3), 221.

24. Shemesh, O., Golbetz, H.M., Kriss, J.P., \& Myers, B.D. (1985). Limitations of creatinine as a filtration marker in glomerulopathic patients. Kidney International, 28:830-6

25. Bauer, J.H, Brooks, C.S., \& Burch, R.N. (1982). Clinical approach of creatinine clearance as a measurement of GFR. Journal Kidney Diseases, 2:337-46

26. Newman, D. J., Thakkar, H., Edwards, R. G., Wilkie, M., White, T., Grubb, A. O., \& Price, C. P. (1995). Serum cystatin $\mathrm{C}$ measured by automated immunoassay: a more sensitive marker of changes in GFR than serum creatinine. Kidney international, 47(1), 312-318.

27. Moses, H. (2012). The Faithful Sixth: A History of the Sixth Battalion the Durham Light Infantry. Memoir Club.

28. D'Agati, V., Suh, J. I., Carbone, L., Cheng, J. T., \& Appel, G. (1989). Pathology of HIV-associated nephropathy: a detailed morphologic and comparative study. Kidney international, 35(6), 1358-1370.

29. Kamga, H. L. F., Assob, J. C. N., Njunda, A. L., Nde Fon, P., Nsagha, D. S., Atanga, M. B. S., ... \& Achidi, E. A. (2011). The kidney function trends in human immunodeficiency virus/acquired immune deficiency syndrome (HIV/AIDS) patients at the Nylon District Hospital, Douala, Cameroon. J AIDS HIV Res, 3(2), 30-37.

30. Emejulu, A. A., Onwuliri, V. A., \& Ojiako, O. A. (2011). Electrolyte Abnormalities and Renal Impairment in Asymptomatic HIV-infected Patients in Owerri, South Eastern Nigeria. Aust J Basic Appl Sci, 5(3), 257-260.

31. Jerzy, J., Alicja, W.D., Tadeusz, W.L., Danuta, P., Magdalene, R., \& Anna, P. (2006). Does HAART improve renal function? An association between serum cystatin C concentration, HIV viral load and HAART duration. Antiviral therapy, 11:841-845

32. Newman, D.J., Thakkar, H., Edwards, R.G., Wilkie, M., White, T., Grubb, A.O., \& Price, C.P. (1994). Serum cystatin C: a replacement for creatinine as a biochemical marker of GFR. Kidney International. (Suppl); 47:S20-1.

33. Nilsson-Ehle, P., \& Grubb, A. (1994). New markers for the determination of GFR: iohexol clearance and cystatin C serum concentration.Kidney International;47(Suppl):S17-9.

34. Grubb, A., Simonsen, O., Sturfelt, G., Truedsson, L., \& Thysell, H. (1985)."Serum concentration of cystatin C, factor D and beta 2-microglobulin as a measure of glomerular filtration rate". Acta MedicaScandinavica, 218(5): 499-503.

35. Newman, D.J., \& Price, C.P. (1999). Renal function and nitrogen metabolites. In Burts, C. A., Ashwood, E.D, eds Tietz textbook of clinical chemistry.3rd Edition. Philadelphia PA: Saunders, 1251-4 